\title{
The Role of Intra-Religious Conflicts in Intrastate Wars
}

\author{
ALEXANDER DE JUAN \\ German Institute of Global and Area Studies, Hamburg, Germany
}

\begin{abstract}
Many civil wars are fought between members of different religious communities. It seems plausible to focus on these communities' interrelations to identify the causal fac tors responsible for the escalating effects that religion can have in such conflicts. A closer look, however, reveals that processes within religious communities can be crucial in influencing the role religions play in intrastate wars. Within single communities, factions of religious elites compete for material and dogmatic supremacy. Such intra religious conflicts can motivate religious elites to search for support from political allies to prevail over their religious rivals. In return, they legitimize their political patrons' claims for political power and their violent campaigns against members of other religious com munities. Thus, intra religious conflicts can effectively contribute to the religious escala tion of intrastate wars between different religious communities. This argument is exemplified with reference to conflicts in Thailand, The Philippines, and Iraq.
\end{abstract}

Keywords conflict, ethnicity, identity, ideology, Islam, religion

\section{Introduction}

Religions play an important role in many intrastate wars: violence erupts along the borders of different religious communities; soldiers pray for God's help before they go to war; churches and mosques are used for recruitment, to store weapons, and to gather the fighters. Apparel and uniforms are decorated with religious symbols instead of nationalist and political insignias. Violent conflicts in Nigeria, Sri Lanka, Israel, and Afghanistan demonstrate that this religious dimension of intrastate conflicts can contribute to violence.

Academia and practitioners are searching for possibilities to counteract these escalating effects of religion. Understandably, they focus on religious communities' interrelations. The premise is that mutual understanding and respect are essential for preventing religions from playing an escalating role in conflicts between different religious communities. Inter-religious networks and councils are being built up to improve interrelations between the believers and thus contribute to the de-escalation of the conflicts.

Due to this concentration on the interrelationship of different religious communities, another significant factor is often overlooked: processes within single

Alexander De Juan is a Research Fellow at the German Institute of Global and Area Studies.

Address correspondence to Alexander De Juan, German Institute of Global and Area Studies, Neuer Jungfernstieg 21, 20354 Hamburg, Germany. E mail: dejuan@giga hamburg.de 
religious communities can influence the role religions play in civil wars. This is not a new discovery. Conflicts between "radical" and "moderate" factions of Muslim communities are being stressed in analyses of intrastate conflicts in Lebanon, Egypt, Algeria, and Pakistan. However, studies on intra-religious conflicts tend to focus on their role in political or violent conflicts within the respective religious communities. However, what is often neglected is the fact that intra-religious rivalries can affect the dynamic of conflicts between different religious communities. In trying to prevail over their religious rivals, religious elites may try to get political support consisting of specific laws and concessions or active political discrimination and suppression of competing religious leaders. But such political help does not come for free. Influential political patrons expect services in return, like religious legitimacy for their political programs or religious justification of their violent struggle against their own political rivals. Especially in religiously diverse societies, political elites will tend to present themselves as defenders of their respective ethnic and religious communities, so as to legitimize their claim for leadership and to mobilize support. ${ }^{1}$ Their chances of success will be higher if they are supported by influential religious elites who publicly confirm their religious rhetoric. Such effective religious mobilization can in turn contribute to the escalation of intrastate conflicts. ${ }^{2}$

In this article I will elaborate on this argument and illustrate how rivalries between different religious factions can influence intrastate wars directly and indirectly. First, I will demonstrate how religious elites can play a central role in violent conflicts. The second section will illustrate how their behavior can be influenced by intra-religious conflicts. Finally, I will support my thesis on the basis of three empirical examples. The last section summarizes my arguments.

\section{The Role of Religious Elites in Political Conflicts}

People's willingness to support violent groups does not depend only on objective grievances. Subjective interpretations of individual living conditions and the prospects of successful improvement of their situation are equally important. ${ }^{3}$ Furthermore, congruence of peoples' individual perceptions is essential for successful mobilization. Larger parts of the population will support violent struggles only if they share a common view of how their situation is to be interpreted and how it is to be changed. ${ }^{4}$ Religion can contribute to the escalation of conflicts when it is part of such common interpretations: Fragmented groups can be integrated on the basis of common religious myths, beliefs, and rituals. Religion can also be used to emphasize fundamental differences to other religious communities. ${ }^{5}$ If a conflict is framed in a transcendental context, negotiated conflict resolution is ruled out as religions and beliefs cannot be bargained. ${ }^{6}$ Finally, the proclamation of heavenly rewards and punishments can increase people's readiness to bear the costs of war. ${ }^{7}$

Quantitative studies confirm that religion can effectively contribute to conflict intensity and duration: Monica Duffy Toft observes that conflicts in which religion plays a key role are fought more intensively and last longer than other conflicts ${ }^{8}$ while Isak Svensson finds that the probability of peaceful conflict resolution is lower if one of the conflict parties has explicit religious aims. ${ }^{9}$

Thus, if religions become part of conflict interpretations, they can contribute to the escalation of conflicts. But how does this happen? Collective religious interpretations will only evolve if they are proposed and spread centrally. ${ }^{10}$ Thus, in suggesting an answer to this question, I will focus on the role of religious elites. There are other 
dimensions of religion that have to be taken into account, like religious identities, ideas, and organizations. ${ }^{11}$ Religious elites' intentional behavior is often neglected in the study of the role of religion in violent conflicts. However, especially if short-term dynamics are to be explained, elites' decision-making has to be taken into consideration. Moreover, religious elites' behavior can effectively influence other dimensions of religion. They shape people's religious identities and religious discourses as well as the structure of religious organizations. Therefore, in the remainder of the article I will concentrate on the role of religious elites in violent conflicts.

Every religious community has a religious elite: people who are accepted by the believers as legitimate interpreters of religious dogmas. They explain the reality in the light of their specific belief systems. They apply abstract religious ideas and provide the believers with concrete religious norms and guidelines. ${ }^{12}$ Max Weber emphasizes that religious ideas will only be influential if they are disseminated by such religious experts and practitioners through religious structures and organizations. Similarly, Nancy Ammermann stresses that religious elites play a central role in the constitution of religious identities. They communicate specific narratives and shape the religious self-conception of the believers. ${ }^{13}$

Religious elites' influence is not restricted to quotidian norm setting. It can also apply to the constitution of radical religious conflict interpretations. In their essence, religious calls for violence do not differ from other theological positions. In every religious belief system there are traditions, scripts, and myths that can be used to legitimize violence. Religious elites can disseminate radical religious messages drawing on these specific religious elements. ${ }^{14}$

Thus, religious elites can effectively legitimize violent campaigns on the basis of religious norms and thus contribute to mobilization and conflict escalation. In doing this, they do not act in a structural vacuum. The impact of their calls for violence will depend on various context factors, such as the role of religion in peoples' everyday lives, specific local religious traditions, or their congruence with other cultural or social norms. ${ }^{15}$ However, if such processes of religious norm setting succeed, violent conflicts will emerge that portray a strong religious dimension. This, in turn, will likely contribute to the intensity and the duration of the conflicts.

Obviously, religions do not only contribute to violence. Their role in violent conflicts is ambivalent. Whereas they foster violence in some settings, they have proven to be effective resources for peaceful change in others. ${ }^{16}$ Similarly, religious elites do not only contribute to the escalation of conflicts but also to their de-escalation. As religious norm setters, they can promote peace by questioning radical (religious) mobilization, by condemning violence and calling for peace on the basis of their respective religious traditions or by actively using the material and financial resources of their communities to support peace and mediation processes. The commitments of the Grand Ayatollah Sayyid Ali al-Husayni al-Sistani in Iraq or the Dalai Lama in Tibet are cases in point. ${ }^{17}$

While I acknowledge the ambivalent role of religious elites in violent conflicts, in the remainder of this article, I will focus on the escalating influence that their behavior can have. Notably, I want to concentrate on the question of why religious elites would be ready to act in a way that contributes to the escalation of intrastate conflicts. I want to have a closer look at the motives of religious elites to call for violence, rather than at the structural prerequisites of their success. Case studies reveal that conflicts between different factions of religious elites within single religious communities play a central role in this respect. 


\section{The Role of Intra-Religious Conflicts}

It is a crucial goal of religious actors to protect and expand the realms of their religious influence. ${ }^{18}$ This aim can derive from sincere religious beliefs or from pure self-interest. Clerics can aim at increasing their religious influence to improve their personal status within their religious community and society at large or because they are convinced that they support the growth of true religion. Regardless of whether they are motivated by personal ends or by religious convictions in trying to secure and expand their influence they will be challenged by other religious elites with similar aims.

Such competition does not only exist between religious communities but also within them. Differing theological positions, world views, and religious concepts of social order can co-exist in single religious communities. Elites will try to defend their own views and religious beliefs against competing ones and they may strive for key positions that will enable them to prevail over their competitors. ${ }^{19}$ Their aim is to consolidate their theological convictions and to strengthen their access to material and organizational resources within their communities. Such intra-religious competitions can influence the course and the intensity of intrastate conflicts in two different ways.

Their direct impact is straightforward. Intra-religious rivalries between factions of religious elites can contribute to violence between the respective factions of believers. Competing religious elites try to mobilize their followers against their rivals to establish their predominance within their religious community. In extreme cases, they disseminate calls for violence aimed against members of the competing faction.

The religious environment in Nigeria is not only characterized by conflicts between Christian and Muslim groups. Both religious communities are factionalized themselves. In the past, the increasing number of different Muslim communities and preachers has contributed to violent communal clashes between different Muslim factions. In trying to stabilize and expand their influence, religious elites have tried to mobilize their constituencies against rival religious groups. Time and again, these religious mobilization campaigns have led to violent clashes. ${ }^{20}$

Intra-religious rivalry had a similar impact within the Sikh community in the Indian Punjab region. In the early 1980s, Jarnail Singh Bhindranwale led a violent fight against the Nirankari, a spiritual movement within Sikhism. These violent clashes resulted from an intra-religious conflict between orthodox and spiritual religious elites. The former denounced the latter's "heretical" beliefs and negated their right to exist. With rousing sermons, Bhindranwale mobilized his followers against the Nirankari. ${ }^{21}$

In many Muslim communities, clerics have lost their traditional religious monopoly. A stratum of new religious intellectuals has emerged. They have acquired their knowledge independently from traditional authorities. Some of them try to mobilize support against the political and religious establishment so as to enforce their own claim for leadership. ${ }^{22}$ Intrastate conflicts based on such intra-religious rivalries have taken place in Egypt and Algeria.

This direct impact of intra-religious conflicts is easily observable and comprehensible as the parties to the conflict are congruent to the competing factions of religious elites. However, intra-religious conflicts can also contribute to conflict escalation in an indirect way. Intra-religious rivalries can lead to the escalation of conflicts between different religious communities. Contrary to the above illustrated 
cases, the competing religious factions are not congruent to the parties to the intrastate conflict; religious calls for violence are not aimed at religious rivals within the community but against a third party.

This indirect impact can result from the pressure that intra-religious rivalries can exert on religious elites. In order to prevail over their competitors, they search for support from political actors. Influential political elites can provide them with financial assistance, or favorable institutional and juridical conditions. Moreover, organizational concessions can consist of the discrimination against and suppression of rival religious factions and leaders.

In return, the political patrons may demand the clerics' support: religious legitimization of claims for political power or religious calls for violence. Such religious backing can help political actors to mobilize believers against their political opponents. This holds especially true for religiously diverse societies. In such situations religious rhetoric against other religious communities can be an effective means of mobilizing popular support and claiming political leadership ("defender of the religious community"). It can also boost mobilization in violent conflicts as it can be used to construct in-groups and out-groups, to rule out peaceful conflict resolution, and to increase people's willingness to bear the costs of violent conflicts. ${ }^{23}$ Considering religious elites' crucial role in religious norm setting, political actors will be interested in receiving their backing to increase the credibility of their radical religious rhetoric. In return, religious elites will be motivated to support political elites' violent campaigns against other religious communities in order to receive assistance against their intra-religious rivals.

Hence, intra-religious conflicts can lead to religious escalation of conflicts between different religious communities, when they motivate religious elites to support violent political campaigns that are aimed against the members of another religious community. ${ }^{24}$ Such effects of intra-religious conflicts are hard to identify because the borders of the violent conflict do not run parallel to the intra-religious conflict. Contrary to the direct impact of intra-religious conflicts, the religious calls for violence are not aimed against those religious factions that motivate the religious elites to disseminate their radical religious interpretations in the first place. Whereas the direct impact of intra-religious conflicts is being analyzed in many cases, the indirect impact is often neglected. In the remainder of this article I will concentrate on the latter.

\section{Types of Intra-Religious Conflicts}

Theoretically, two typical kinds of intra-religious conflicts can be differentiated. The first is centered around religious ideas and dogmas. Thus, it can be considered "religious" in the actual sense of the term as the cause of the conflict consists of differences in religious agendas, values, and doctrinal interpretations. The second is focused on religious elites' attempts to maximize their influence and access to material resources within their religious community. Consequently, it is not the conflict itself that is to be considered religious. Rather, worldly conflicts about financial resources and power take place within religious communities. Thus, it is not the cause of these conflicts that is religious but the arena in which they take place.

Empirically, these two theoretical types of intra-religious conflicts cannot be differentiated effectively. Religious elites' actual motives can hardly be identified accurately. Furthermore, rivalries are often based on some kind of combination of both 
theological and material aspects. Elites try to maximize their access to material resources and political power so as to strengthen their ability to make their own religious ideas and doctrinal interpretations the dominant religious discourse within their community. In concrete cases it will hardly be possible to specify whether such behavior (and conflicts that might result from it) has to be classified as being truly religious or rather political/financial. However, for the sake of illustration, I will describe these two types of intra-religious conflicts separately.

\section{Dogmatic Religious Conflicts}

Within religious communities, religious elites' theological positions, world views, and concepts can collide. ${ }^{25}$ Different factions of religious elites and believers try to make their own views and interpretations prevail over rival ones. If they are not successful on their own, they will try to win the support of influential political actors. On many occasions, clerics have cooperated with violent, nationalist elites in order to win their support in such theological conflicts. The impact can be observed in Sri Lanka or Bosnia.

The Sri Lankan Buddhist establishment is factionalized along different theological lines. The rivalry of two major religious blocs has had a major impact on Sri Lanka's civil war. Whereas the first sees the monks' primary social role in rural development, the second concentrates on spreading the Buddhist culture. When the Sri Lanka Freedom Party (SLFP) was established, the latter saw it as a chance to prevail over their religious rivals. They cooperated with the nationalist SLFP and legitimized its violent campaign against the predominantly Hindu and Muslim Tamil minority in return for political support against their theological intra-religious competitors. ${ }^{26}$

With the end of the communist Tito regime, the Serb Orthodox Church in Yugoslavia was freed from a long era of manipulation and suppression. A neoconservative group of mainly young religious elites tried to establish connections to a new nationalist intelligentsia in Serbia. ${ }^{27}$ They perceived the rise of Serb Nationalists led by Slobodan Milosevic as a chance to foster their position within the Serb Orthodox Church. They provided the nationalists' expansive anti-Catholic and anti-Muslim political program with religious legitimacy. In return, they received political support helping them to strengthen the church's social influence and to establish their supremacy within the orthodox religious establishment. ${ }^{28}$

\section{Material Conflicts}

Intra-religious conflicts can also stem from conflicting material interests. In many developing countries institutionalized churches constitute one of the few possibilities to acquire wealth and power. Hence, competition for material resources and influence can emerge in religious communities, comparable to state structures. Referring to the Catholic Church in Africa, Jean-François Bayart emphasizes that many young clerics act as religious, economic, and political entrepreneurs trying to maximize the profit they can make out of their clerical position. ${ }^{29}$ In trying to access the material resources of their religious community, they are competing with other religious elites. Such rivalries can motivate them to align with influential political actors to receive their support in securing access to the community's material resources.

In Rwanda, clerical Hutu elites used their strong connections to the Habyarimana regime to secure their dominant position within the Catholic Church. 
In the 1990s, the Catholic hierarchy was under mounting pressure due to increasing calls for a reformation within the church. Simultaneously, charismatic lay movements within the church grew in importance. The established hierarchy felt its privileged position threatened and kept up its strong connection to political elites even in the wake of the beginning genocide, to secure its clerical supremacy. As a result, many Catholic clerics actively or passively supported the regime's violent campaign and its religious underpinning. ${ }^{30}$

Most Muslims in Chechnya belong to one of the two major Sufi orders Naqshbandiyya and Qadiriyya. Traditionally, the relationship between the two orders has been characterized by competition over social and political influence. In the wake of the "first Chechen war," religious elites of the Qadiriyya cooperated with Dzhokhar Dudayev's nationalist government, hoping for its support against the Naqshbandiyya. Dudayev reformed the state's religious structure and transferred religious key positions from the Naqshbandiyya to the Qadiriyya. Thus, at the beginning of the war it was primarily the Qadiriyya that sanctioned the regime's religious calls for violence against the "infidel" Russian troops. ${ }^{31}$

\section{Hegemonic Conflicts}

As mentioned above, the differentiation of dogmatic and material intra-religious conflicts is mainly theoretical. Combinations of both types can be observed in most cases: religious factions that differ in their ethnic or regional origin or in their religious beliefs, political affiliations, or world views compete for religious influence, religious supremacy, and access to the community's material resources. In short, they compete for hegemony within the community.

In such hegemonic conflicts, the probability that one faction will search for political support will be high, if its members' access to religious positions and material resources is systematically blocked because they belong to a specific regional, ethnic, or dogmatic faction within the community. Such restrictions can be the result of political discrimination or the other faction's consolidated dominance. If one of the factions is already closely aligned with influential political elites, it might use its political support to systematically shun its rivals from access to religious influence. Similarly, in highly institutionalized and formalized religious communities, dominant religious elites can use their control over intra-religious rules and regulations to systematically keep members of rival religious factions from gaining influence within formal religious structures.

In both cases, the inferior faction may try to find other ways to prevail over its rivals. It may, for example, search for political elites' support. In return, they provide their patrons with religious legitimacy. In political or violent conflicts between different religious communities, they might confirm political leaders' radical religious agitations and may thus support the religious escalation of the respective conflicts.

In the remainder of the article I will illustrate how hegemonic conflicts within religious communities can shape violent intrastate conflicts between different religious communities. I do not aim at extensive analyses of these cases. Rather I want to illustrate how competition between different religious factions can result in religious elites' support for radical political movements. Muslim rebel movements in Thailand, Iraq, and the Philippines serve as examples. I have chosen these cases because they display important similarities: in all three Muslim communities, protest movements emerged that challenged the hegemony of established religious elites. 
In all three cases, religious elites within these movements supported violent rebel groups as a means to end the supremacy of rival clerics. And in all of these cases, this religious support effectively shaped the course of violent conflicts with other religious communities. Even though the empirical case studies do not meet the requirements of actual comparative analysis (as regards case selection and analysis of control variables), their striking similarities demonstrate the plausibility of the argument that intra-religious conflicts can effectively shape intrastate wars.

For all of the following three cases, I will show that a) religion played a major role in the mobilizing ideology of the respective violent movements and their political leaders, b) religious elites played a central role in disseminating these movements' radical religious propaganda, and c) that intra-religious hegemonic conflicts ${ }^{32}$ played an important role in motivating religious elites to support the violent movements' religious mobilization against the members of other religious communities.

\section{Case Studies}

\section{Thailand}

Inter-religious relations in southern Thailand have traditionally been quite harmonious. ${ }^{33}$ However, when the government in Bangkok started to restrict the region's traditional autonomy rights in the early 20th century, frictions between the Muslim and Buddhist communities increased. Local Muslim political elites lost their power to Buddhists faithful to the Thai government. Many of those that were deprived of their power started to advocate for the region's secession from Thailand and its association with Malaysia. Lack of self-determination, slow economic development, and state-fostered immigration of Buddhists from northern regions led to further escalation of the conflict between the government and the Muslim population in the region. Turmoil and riots followed. The situation calmed down during the Second World War but escalated again in the 1960s. Several rebel groups emerged that tried to enforce autonomy of Muslim Mindanao against the central government by violent means. ${ }^{34}$

The first Muslim rebel groups legitimized their fight against the government with an ethnic agenda ${ }^{35}$ However, in the early 1970s they started using religious calls for violence to mobilize the population. An analysis of the pamphlets of the rebel group Patani United Liberation Organisation demonstrates the religious essence of the rebels' propaganda. They emphasized the inner unity of the Muslims and their distinctiveness from the majority Buddhist population. Simultaneously, they resorted to verses from the Koran to demonstrate the superiority of their own religion as compared to Buddhism. Finally, they called the believers to take up arms against the "nonbelievers." The increasing importance of religion in the rebel movement is mirrored by the separatist organizations' names: violent groups were renamed or newly formed so as to correspond to the new leading ideology, like the United Mujahedin Front of Patani or the Islamic Liberation Front of Patani. ${ }^{36}$

In persuading the population of the religious necessity to fight the government, the rebels were supported by Muslim religious elites. They were responsible for recruitment and training. Most importantly, they disseminated the rebels' religious calls for violence and thus contributed to the credibility and the success of the religious propaganda. ${ }^{37}$ Interviews with the local population confirm that numerous religious leaders had helped to persuade the believers that the violent fight against 
the Buddhist government was a religious necessity. Still today, religious teachers play a central role in supporting the rebels' leadership and in providing religious legitimacy to the use of violence. ${ }^{38}$

Why did religious elites behave this way? Intra-religious conflicts within the Muslim community played a central role in their support to the rebels' radical propaganda. The majority of the Muslims belong to the Shafi school of Sunni Islamic thought. However, their religious tradition differs from orthodox doctrines and practices. ${ }^{39}$ Religious schools and mosques teach a kind of Islam that has been influenced by other belief systems. Its rituals and customs are characterized by overlaps with Buddhist, Hindu, and local spiritual traditions such as the use of magic objects or the belief in spirits and magical healing. This dominant traditional form of Islam has been challenged by a reformist Muslim movement that has gained in importance since the 1960s. Originally, its members mainly came from foreign countries and engaged against secularization and consumerism and for a purification of Islam. ${ }^{40}$ The reformist movement was strengthened when more and more Muslims received stipends from Islamic countries and private organizations that allowed them to pursue religious studies in India and the Middle East. Since the 1990s, many of the returnees did not go back to their religious home communities. Rather they tried to open up new religious schools, to gain religious influence, and to establish themselves as religious elites against the dominant traditional form of Islam. ${ }^{41}$

Thus, an intra-religious rivalry evolved with the growing influence of the reformist movement. The local population started to distinguish between two distinct Muslim groups: the "kaum tua," the traditionalists, and the "kaum muda," the reformists/modernists. The latter distanced themselves from prevailing religious practices, and tried to "clean" the believers from traditional elements of folk Islam. Their condemnation of "impure" Islam challenged the religious influence of traditional religious elites. Over the years, the distinction between traditionalists and modernists blurred as waves of young Muslims returned from abroad with new, progressive ideas and distanced themselves from the dominant elites and practices at home whether these ideas were originally traditionalist or reformist. Hence, the rivalry evolved into a competition between established religious elites and young Muslim modernists. ${ }^{42}$

When looking at the rebel movement, it is striking that religious support has been mainly restricted to the group of young clerics and religious elites that were trying to establish themselves against the hegemony of traditional religious elites. Many of these young Muslims did not possess the financial resources required to build their own religious schools or mosques. More importantly, their religious studies abroad were not recognized by the Thai government. By not accepting their foreign degrees, the government denied them access to religious positions. Thus, many young clerics were systematically excluded from access to religious influence. Many of them had to reluctantly work in existing religious schools. As graduates from Arabic schools, they were often better qualified than the principal religious teachers. Hence, they were subordinate to religious elites whose religious beliefs they did not share and against whom they were not able to prevail. Analyses of the current conflict show that many members of this group of young religious elites have been particularly engaged in support of rebel groups and the dissemination of radical ideologies. ${ }^{43}$ For these marginalized young clerics, the rebel movement constituted a promising ally against their intra-religious rivals. Rebels fought the government for secession of southern regions from the Thai state. This corresponded to the interests of marginalized religious 
elites: with its policy of patronage the government supported the religious establishment and excluded young clerics from these structures. Thus, many young Muslims supported rebel groups against common enemies as a means to end their rivals' religious hegemony and strengthen their own religious influence within the Muslim community in southern Thailand. Undoubtedly various personal, political, and social aspects have been essential in persuading individual young Muslim elites to support the violent struggle against the Thai government. However, based on the descriptions above, it can convincingly be argued that the intra-religious conflict between deprived young clerics and the religious establishment played an important role in contributing to the religious escalation of the violent conflict between the Muslim minority and the Thai government.

\section{Iraq}

When the Baath regime was overthrown in 2003, a political vacuum was created. Several political and armed groups competed for political leadership. In the same year the number of Sunni terrorist attacks on Shiite targets increased significantly. ${ }^{44}$ A central rationale of the violence has been radical Sunnis' hope to trigger a civil war that would plunge the country into chaos and lead to the withdrawal of foreign troops. At first, from 2003 to 2005, this aggression barely led to retaliatory acts on the part of the Shiite community. It was only after the first elections in the year 2005 that the number of Shiite violent acts against Sunnis increased. The Shiite Jaysh al-Mahdi has been one of the major violent protagonists. The group was founded after the fall of the Baath regime by the young Shiite cleric Muqtada al-Sadr. He has quickly been able to gather support in the slum districts of Baghdad. In 2006 and 2007, his militia was able to control substantial parts of the capital through "sectarian cleansing.",45

Religion has always played a central role in the Jaysh al-Mahdi. Its religious mobilization campaign was mainly directed towards the violent fight against U.S. troops and to a lesser extent against the Sunni population. Muqtada al-Sadr declared the "coalition of the willing" a threat to the return of the hidden Imam and the beginning of a golden Islamic era. The members of the Interim Governing Council were called "infidels" and "traitors." He interpreted the use of violence as a good religious deed in favor of the hidden Imam that justified the sin of killing. ${ }^{46}$ In the context of the Shiite-Sunni conflict, Sadr's rhetoric has been more differentiated. He condemned acts of violence against the community of the Sunnis: "I call on Muslims, Sunnis and Shi'ites, to be brothers. ... Faith is the strongest weapon, not arms." 47 However, at the same time he called for the fight against "Wahabis" and members of the old Baath regime. Radical Sunnis were declared "Nawasib" enemies of the family of the Prophet. ${ }^{48}$ Such a differentiated rhetoric provided his militia with sufficient interpretative leeway and religious legitimization to use violence against Sunnis when deemed necessary.

The Jaysh al-Mahdi has been able to mobilize parts of the Shiite population because it was able to persuasively interpret the Sunni-Shiite conflict in religious terms. Support from religious elites was essential in this regard. Even though al-Sadr is a low-ranking Shiite cleric himself, he was in need of support from other local religious elites to disseminate his religious messages to the population. As a matter of fact, local religious elites constituted the backbone of his political-religious movement. Most of them have aborted their religious studies prematurely. They preach in 
small mosques within the areas controlled by the Jaysh al-Mahdi and spread Sadr's religious interpretations to the Shiite believers. Many of them have publicly called for violence against the members of the Baath party and "radical Sunnis."49

Why did so many young clerics decide to support the Jaysh al-Mahdi? Intrareligious conflicts played a major role in convincing them to join the movement and support its radical religious rhetoric against foreign troops and Sunnis. Shiite intra-religious rivalry can be traced back to a cleavage within the Shiite clerical class. Put simply, it can be said that a rather apolitical faction is competing with a political one. The first does not call for the religious elites to be detached from any kind of political engagement. However, it rejects the idea of religious elites taking over direct political responsibility. Traditionally, the majority of this faction belongs to the Usuli School of Thought. According to this school, every believer has to choose a living cleric whose religious interpretations he will follow. The religious authority of these "sources of emulation" is based on formal religious knowledge. ${ }^{50}$

Members of the political faction, on the other hand, call for a politically active Shiite clergy that is ready to take over political responsibility. Radical members demand the subordination of any political decision under the scrutiny of the religious elite. The majority of them refute the Usuli School's strict concept of authority. In the 1970s, Baqir-al-Sadr introduced the distinction between different kinds of religious elites: the ones whose religious authority is based on their profound religious knowledge and others whose legitimate authority is based on the fact that they are aware of the needs of the believers and that they are active in the name of their communities. This interpretation has been stressed by other members of the Sadr family to legitimize their claim for religious authority against the members of the Usuli School. ${ }^{51}$

To date, these two factions fight over hegemony within the Shiite community. They compete for access to important Shiite mosques, educational centers, and religious alms. This rivalry is especially apparent in the Shiite areas in eastern Baghdad, in Kerbala, Kufa, and Basra. Within these centers of the Shiite religious community, both factions try to monopolize the principal religious sites. ${ }^{52}$ The conflict is especially intense in Najaf, the spiritual and financial capital of the Shiites in Iraq. The Shrine of Imam Ali is situated in the city and it hosts the Hawza-al Illmiya a network of religious seminars and institutions, led by the most high-ranking Shiite clerics. Thus, the dominant religious authorities in the city control the most important seminars and mosques of the Shiite community. On several occasions members of the Sadr family have tried to seize control over the city. ${ }^{53}$

This intra-religious conflict has shaped the violent conflict between Shiite and Sunni groups. Most religious elites in the Jaysh al-Mahdi belong to the political faction. The consolidated hegemony of the apolitical faction and its severe formal requirements prevented any easy access to religious positions and influence. Many young religious elites failed in the conventional religious educational system. Alternatively, they tried to boost their religious influence by joining the Jaysh al-Mahdi, which was explicitly aiming to end the hegemony of the apolitical faction and its formal system of religious authority. Thus, many young clerics of the political faction conceived of the movement as a chance to abolish formal obstacles to religious influence, to establish themselves as religious leaders against the official Hawza-al Illmiya, and to get access the community's financial and material resources. Muqtada al-Sadr has mainly been supported by these young, local elites who were not able to succeed within the religious establishment. They rebelled against the official religious structures and used the Mahdi movement as both a mouthpiece and vehicle 
to gain religious influence against the dominating apolitical faction. ${ }^{54}$ However, joining the Jaysh al-Mahdi also meant subscribing to its anti-Sunni agenda and supporting it in mobilizing the believers against "radical Sunnis." Undoubtedly, many young Muslims joined the Jaysh al-Mahdi out of personal conviction that the fight against Sunni groups and the apolitical faction of their religious community was a religious necessity. However, the intra-religious conflict described above shaped the composition of the Jaysh al-Mahdi and contributed to the dissemination of its radical religious agenda.

\section{The Philippines}

The conflict of the Muslim "Moro" and the Philippine central government can be traced back to the Spanish occupation of the Philippines in the 16th century. Whereas large parts of the country were quickly controlled and proselytized by the Christian colonial power, the Muslim regions in the south of the Philippines offered fierce resistance to the occupation. The Spanish called the Muslims "Moros" as they had the same religion as the "Moors," Muslim Arabs who conquered and then occupied the Iberian Peninsula until the 15th century. After the Spanish-American War, the Philippines were transferred to the United States in 1898. Following initial military clashes, the new power changed its strategy and tried to integrate the traditional Muslim elites into the state administration. However, after the Philippines' independence in 1946, relations between the "Moros" and the Christian majority deteriorated further. Political and economic discrimination and state-promoted mass migration of Christians from the north to the Muslim south played a central role in the continuous escalation of the conflict. The first rebel movements were founded among the "Moros" in the 1960s. They engaged the central government in a violent conflict that later evolved into a full-fledged civil war. ${ }^{55}$

At first, the discourse of the rebel movement was mainly ethno-national in nature. Its founders and leaders primarily stemmed from leftist student movements. Their proclaimed aims were autonomy, an end to the discrimination of the "Moro people," and a more equitable distribution of land among Muslims and Christians. ${ }^{56}$ By the end of the 1970s, this ethno-national discourse was replaced by a more radical religious interpretation of the conflict. Islam became the primary element of the rebels' mobilizing ideology when the Moro Islamic Liberation Front (MILF) was formed: "All Mujahideen under the ... MILF adopt Islam as their way of life. Their ultimate objective in their Jihad is to make supreme the WORD of ALLAH and establish Islam in the Bangsamoro homeland." ${ }^{57}$ Whereas the initial rebel movements aimed at the establishment of an independent state, for the MILF independence was just the means to a higher end: the protection and dissemination of Islam and the Will of God. ${ }^{58}$ This reorientation of the rebels' discourse effectively strengthened its public support and resulted in a strong religious connotation and escalation of the conflict. Support from Muslim elites was essential in convincing believers of the rebels' new religious propaganda.

Many Muslim clerics were active in the rebel movement and supported its violent fight against the government. Religious elites were integrated into the rebel forces and took over principal functions in the movement. Additionally, the MILF was supported by imams and religious teachers in local mosques and religious schools. ${ }^{59}$ They played a crucial role in the recruitment, organization, and ideological formation of the rebels. Mobilization drives emphasized the religious duty of the Muslims 
to take part in the holy war against the Philippine government. ${ }^{60}$ Thus, the MILF used the support of local religious elites as well as their broad networks of mosques and religious schools to make the movement's new religious agenda accessible to the population. ${ }^{61}$ But why did so many Muslim religious elites provide religious legitimacy to the rebels' radical religious agenda that focused on the religious differences between the "Moros" and the country's predominantly Christian government?

Intra-religious conflicts played a central role in motivating religious elites to support the rebel movement. In the Philippines, Islam has developed in close relation to local religious rites and traditions. Far away from the religious centers of Islam, a religious tradition evolved that has been strongly influenced by its specific cultural surroundings and that integrated local customs, cleansing rituals, and beliefs. Local aristocratic elites, the so-called Datus, traditionally controlled religious elites through structures of patronage. ${ }^{62}$ This dependence explains a central feature of the local Islamic tradition: the legitimization of traditional feudal structures and local strongmen with reference to special religious privileges of the Datus, based on the will of God. ${ }^{63}$ This traditional alliance of religious elites and their patrons has been challenged from the 1960s on. During the Nasser regime in Egypt, thousands of young Muslims in the Philippines received financial support that enabled them to study abroad. Many of them adhered to reformist religious beliefs. Gradually, a new religious elite emerged. Many of its members had a more rigorous interpretation of Islam. ${ }^{64}$ They condemned "religious innovations" in the traditional Islamic belief system and criticized local rites and customs as being "un-Islamic." In this, they not only turned against traditional religious elites but also against the ruling Datus as their political claim for leadership was legitimized by the local religious elite and traditional folk Islam. ${ }^{65}$

The composition of the MILF is a clear indication that the intra-religious conflict played a crucial role in the religious elites' support of the rebel movement and thus to the effective development of a strong religious dimension of the rebellion against the Philippine government. The rebels' radical religious interpretations were mainly promulgated by members of the new religious elite. When they returned from their religious studies abroad, they tried to prevail over the traditional religious establishment and "Folk Islam." However, their access to religious positions and religious influence was artificially blocked by the traditional alliance of religious elites and their political patrons the influential Datus. Thus many members of the new religious elite formed a counter-alliance with young political elites who played an increasingly important role in the political leadership of the rebel movement. Young clerics were directly engaged in the MILF while others established themselves as religious teachers and Imams and became the public mouthpiece of the rebel movement that persuaded the believers of the religious necessity to fight the government. ${ }^{66}$

It cannot be ruled out that other factors were more influential in the religious overtones to the civil war in the Philippines. However, it seems convincing that the intra-religious conflict between traditional religious authorities and the new religious elite led to the formation and consolidation of political-religious alliances that played an important role in shaping the religious dimension of the conflict.

\section{Summary}

Many conflicts are fought between members of different religious communities, as in Sri Lanka, Indonesia, India, Nigeria, and Sudan. The escalatory role of religion in 
such intrastate wars does not simply result from specific religious dogmas and traditions. Neither can it be traced back to specific differences between various religious communities' doctrines. Religions are not isolated from political or social factors. ${ }^{67}$ Their institutions, elites, and ideas are closely linked to social and political organizations, actors, and ideologies. The role of religion in conflicts is shaped by the nature of these interrelationships. Thus, if we want to understand how religions can contribute to the escalation of intrastate conflicts, we have to analyze how religions interact with the political and social spheres. In this article, I have argued that conflicts between rival religious elites can be powerful motives for them to ally with political actors and to influence political processes. In many cases this resulted in religious-political alliances that contributed to the escalation of intrastate conflicts.

Religious elites play a central role in many violent conflicts. They can interpret them in religious terms and disseminate radical religious interpretations among the believers. Without such religious interpretation work, radical religious calls for violence would lack necessary religious credibility to act as effective tools for mobilization. Accordingly, religious elites play a major role in determining the way in which religions influence the course of violent intrastate conflicts. If they successfully frame conflicts in religious terms, they contribute to the duration and intensity of violent conflicts. Empirical studies demonstrate that civil wars that display religious underpinnings are fought more intensively and are harder to end peacefully. This raises the question of why religious elites would be involved in contributing to the religious escalation of conflicts between members of different religious communities.

Undoubtedly, differences between religious communities can play a central role in civil wars. However, in many conflicts it is not the relations between religious communities alone that shape the elites' behavior but the relations between religious elites within single communities.

Within their communities, religious elites try to defend their religious interpretations against rival elites. They try to influence religious discourses and compete with other elites for material and organizational resources in their communities. Such rivalries can directly lead to violence. In these cases violent movements will be formed along the borders of different religious factions. This can be observed in India, Nigeria, and in different Muslim countries. But inner-religious conflicts can also influence intrastate wars indirectly. Clerics support violent political movements against members of other religious communities because they hope for political support against their own intra-religious rivals.

There are two ideal types of intra-religious conflicts: material and dogmatic conflicts. In the first case, material resources are crucial; in the latter case the influence on intra-religious discourses is essential. Combinations of both types are particularly common. Different factions of religious elites compete for material and dogmatic supremacy within their religious communities. In order to illustrate how such conflicts can influence the course of civil wars, I have briefly described three violent conflicts. Hegemonic conflicts can be observed within the Muslim minorities in Thailand and the Philippines as well as in the Shiite community in Iraq. The hegemonic positions of established religious elites are challenged by competing factions of nonestablished clerics. In Thailand and the Philippines, young Muslim clerics returned from studies in foreign countries and tried to establish themselves against traditional religious elites. In Iraq, young adherents to a political form of Islam competed with moderate religious elites for the spiritual and material leadership in the Shiite community. However, in all three cases their access to religious influence was structurally 
blocked by political interference in religious systems and/or by formal requirements set by dominant religious factions. In Thailand, it was the state that blocked young Malay Muslims' access to religious structures. In the Philippines, local feudal structures played a similar role. The formalized concept of religious authority based on knowledge closed young religious elites' way to religious influence. In all three cases, young religious elites have searched for support from political elites or political movements in gaining access to religious influence and ending their rivals' hegemony. In exchange, they have helped to legitimize these actors' and movements' radical religious propaganda und thus contributed to the religious escalation of intrastate conflicts between different religious communities.

Even if further empirical analyses are necessary to determine the causal relevance of intra-religious conflicts, the illustrated cases indicate that crucial factors have been neglected in the analyses of the role of religion in violent conflicts. Intra-religious rivalries can influence religious elites' motives and strategies. If different religious factions compete for financial and organizational resources, the probability increases that one of them will search for political help. In many cases, they support violent movements with radical violent interpretations. In return, they receive the aid they need to prevail over their intra-religious rivals. The risk of such political-religious cooperation will be especially high if one faction's access to religious influence is systematically blocked by political actors or institutionalized mechanisms within the religious community. I do not want to argue that religious elites' behavior may not equally be influenced by other factors such as religious beliefs, political convictions, or personal values. However, the examples outlined above indicate that intra-religious relations and structures play an important role in influencing religious elites' decision-making. Thus, when exploring how religious communities behave outwardly, one has to analyze how they are organized internally.

\section{Notes}

1. See, for example, Michael E. Brown, "The Causes of Internal Conflict: An Over view," in Michael E. Brown, ed., Nationalism and Ethnic Conflict: An International Security Reader (Cambridge, MA: MIT Press, 1997), 3 25; Monica Duffy Toft, "Getting Religion? The Puzzling Case of Islam and Civil War," International Security 31, no. 4 (2007): 97131.

2. Toft, "Getting Religion?" (see note 1 above); Isak Svensson, "Fighting With Faith: Religion and Conflict Resolution in Civil Wars," Journal of Conflict Resolution 51, no. 6 (2007): 930949.

3. Nicholas Jay Demerath, Crossing the Gods: World Religions and Worldly Politics (New Brunswick, NJ: Rutgers University Press, 2001), 179.

4. Colin Barker, Alan Johnson, and Michael Lavalette, "Leadership Matters: An Intro duction," in Colin Barker, Alan Johnson, and Michael Lavalette, eds., Leadership and Social Movements (Manchester: Manchester University Press, 2001), 1 23; David A. Snow, E. Burke Rochford, Steven K. Worden, and Robert D. Benford, "Frame Alignment Processes, Micro mobilization, and Movement Participation," American Sociological Review 51, no. 4 (1986): 464481.

5. R. Scott Appleby, The Ambivalence of the Sacred: Religion, Violence, and Reconcili ation (New York/Oxford: Rowman \& Littlefield, 2000); Jeffrey R. Seul, " 'Ours is the Way of God': Religion, Identity and Intergroup Conflict," Journal of Peace Research 36, no. 3 (1999): 553569.

6. Andreas Hasenclever und Volker Rittberger, "Does Religion Make a Difference? Theoretical Approaches to the Impact of Faith on Political Conflict," in Pavlos Hatzopolous and Fabio Petito, eds., Religion in International Relations: The Return from Exile (New York: Palgrave Macmillan, 2003), 107 145; Theodor Hanf, "The Sacred Marker: Religion, 
Communalism, and Nationalism," in Theodor Hanf, ed., Dealing with Differences: Religion, Ethnicity, and Politics: Comparing Cases and Concepts (Baden Baden: Nomos, 1999), 394.

7. Hasenclever and Rittberger, "Does Religion Make a Difference?" (see note 6 above); Mark Juergensmeyer, "The Worldwide Rise of Religious Nationalism," Journal of International Affairs 50, no. 1 (1996): 120.

8. Toft, "Getting Religion?" (see note 1 above).

9. Svensson, "Fighting With Faith" (see note 2 above).

10. Barker et al., "Leadership Matters" (see note 4 above), 4 5; Aldon D. Morris and Suzanne Staggenborg, "Leadership in Social Movements," in David A. Snow, Sarah A. Soule, and Hanspeter Kriesi, eds., The Blackwell Companion to Social Movements (Malden, MA: Blackwell Publishing, 2004), 171196.

11. Kristian Berg Harpviken and Hanne Eggen / Røislien, "Faithful Brokers? Potentials and Pitfalls of Religion in Peacemaking," Conflict Resolution Quarterly 25, no. 3 (2008): 351 373; Matthias Basedau, "Religion und Gewaltkonflikt im Subsaharischen Afrika: Zur Rolle Religiöser Faktoren in Benin und der Elfenbeinküste," in Margit Bussmann, Andreas Hasenclever, and Gerald Schneider, eds., PVS Sonderheft, Identität, Institutionen und Ökonomie: Ursachen Innenpolitischer Gewalt 43 (2008): 150177.

12. Appleby, The Ambivalence of the Sacred (see note 5 above).

13. Nancy T. Ammerman, "Religious Identities and Religious Institutions," in Michele Dillon, ed., Handbook of Sociology of Religion (Cambridge: Cambridge University Press, 2003), 207224.

14. Gabriel A. Almond, Emmanuel Sivan, and Scott R. Appleby, "Explaining Funda mentalism," in Martin Marty and Scott R. Appleby, eds., Fundamentalism Comprehended (Chicago: University of Chicago Press, 1995), 425 443; Richard E. Wentz, Why Do People Do Bad Things in the Name of Religion? (Macon, GA: Mercer University Press, 1987).

15. See, for example, Alexander De Juan and Andreas Hasenclever, "Das Framing Religiöser Konflikte Die Rolle von Eliten in Religiös Konnotierten Bürgerkriegen," in Margit Bussmann, Andreas Hasenclever, and Gerald Schneider, eds., PVS Sonderheft, Identität, Institutionen und Ökonomie: Ursachen Innenpolitischer Gewalt 43 (2008): 178205.

16. Appleby, The Ambivalence of the Sacred (see note 5 above); Gerrie Ter Haar, "Religion: Source of Conflict or Resource for Peace?," in Gerrie Ter Haar and James Busuttil, eds., Bridge or Barrier: Religion, Violence, and Visions for Peace (Leiden: Brill 2005), 334 .

17. Alexander De Juan and Johannes Vüllers, "Religious Peace Activism The Rational Element of Religious Elites' Decision making Processes," GIGA Working Papers 130, 2010; Alexander De Juan and Andreas Hasenclever, "Grasping the Impact of Religious Traditions on Political Conflicts," Die Friedens Warte 82, nos. 2 (2007): 1948

18. Jeff Haynes, Religion and Politics in Africa (London: Zed Books, 1996); Jonathan Fox and Shmuel Sandler, Bringing Religion into International Relations (New York: Palgrave MacMillan, 2004).

19. Alexander De Juan, "A Pact with the Devil? Elite Alliances as Bases of Violent Religious Conflicts," Studies in Conflict and Terrorism 31, no. 12 (2009): 11201135.

20. Jibrin Ibrahim, "Religion and Political Turbulence in Nigeria," The Journal of Mod ern African Studies 29, no. 1 (1991): 115136.

21. Mark Juergensmeyer, "The Logic of Religious Violence: The Case of the Punjab," Contributions to Indian Sociology 22, no. 1 (1988): 65 88; Peter van der Veer, "The Ruined Center: Religion and Mass Politics in India," Journal of International Affairs 50, no. 1 (1996): 254277.

22. Leland W. Robinson, "When Will Revolutionary Movements Use Religion?," in Thomas Robbins and Roland Robertson, eds., Church and State (New Brunswick, NJ: Transaction, 1986), 53 63; Muhammad Qasim Zaman, The Ulama in Contemporary Islam: Custodians of Change (Princeton, NJ: Princeton University Press, 2002).

23. Hasenclever and Rittberger, "Does Religion Make a Difference?" (see note 6 above); Seul, "Ours is the Way of God"” (see note 5 above), 565.

24. De Juan, "A Pact with the Devil?" (see note 19 above).

25. Hank Johnston and Josez Figa, "The Church and Political Opposition: Comparative Perspectives on Mobilization Against Authoritarian Regimes," Journal for the Scientific Study of Religion 27, no. 1 (1988): 32 47; Haynes, Religion and Politics in Africa (see note 18 above). 
26. Chandra R. De Silva, "Buddhist Monks and Peace in Sri Lanka," in Mahinda Deegalle, ed., Buddhism, Conflict and Violence in Modern Sri Lanka (London: Routledge, 2006), 202 209; Chandra R. De Silva and Tessa J. Bartholomeusz, The Role of the Sangha in the Reconciliation Process (Sri Lanka: Marga Institute, Marga Monograph Series on Ethnic Reconciliation, No. 16, 2006).

27. Radmila Radic, "Die Kirche und die, serbisch Frage'," in Thomas Bremer, ed., Serbiens Weg in den Krieg: Kollektive Erinnerung, Nationale Formierung und Ideologische Aufrüstung (Berlin: A. Spitz, 1998), 187.

28. See, for example, David A. Steele, "Christianity in Bosnia Herzegovina and Kosovo: From Ethnic Captive to Reconciling Agent," in Douglas Johnston, ed., Faith Based Diplomacy: Trumping Realpolitik (Oxford: Oxford University Press, 2003), 124177.

29. Jean François Bayart, Religion et Modernité en Afrique Noire: Dieu pour Tous et Chacun pour Soi (Paris: Karthala, 1993).

30. Timothy Longman, "Church Politics and the Genocide in Rwanda," Journal of Religion in Africa 31, no. 2 (2001): 163 186; Saskia Van Hoyweghen, "The Disintegration of the Catholic Church of Rwanda: A Study of the Fragmentation of Political and Religious Authority," African Affairs 95 (1996): 379401.

31. Alexandre Benningsen and Chantal Lemercier Quelquejay, Le Soufi et le Commis saire. Les Confréries Musulmanes en URSS (Paris: Éditions du Seuil, 1986); Moshe Gammer, "The Qadiriyya in the Northern Caucasus," Journal of the History of Sufism 12 (2000): 275 294; Galina Yemelianova, "Sufism and Politics in the North Caucasus," Nationalities Papers 29, no. 4 (2001): 661 681; Igor Rotar, "Under the Green Banner: Islamic Radicals in Russia and the Former Soviet Union," Religion, State \& Society 30, no. 2 (2002): 89153.

32. In the following case studies I will not differentiate between dogmatic (centered on religious ideas and doctrinal interpretations) and material (centered on financial and political competition) conflicts. As argued above, in most cases intra religious conflicts entail both dogmatic and material elements. Furthermore, in concrete cases, it will hardly be possible to accurately distinguish truly religious and material motives of individual religious elites.

33. Nantawan Haemindra, "The Problem of the Thai Muslims in the Four Southern Provinces of Thailand (Part Two)," Journal of Southeast Asian Studies 8, no. 1 (1977): 85 105; Alexander Horstmann, "Ethnohistorical Perspectives on Buddhist Muslim Relations and Coexistence in Southern Thailand: From Shared Cosmos to the Emergence of Hatred?," SOJOURN 19, no. 1 (2004): 7699.

34. W. K. Che Man, Muslim Separatism: The Moros of Southern Philippines and the Malays of Southern Thailand (Oxford: Oxford University Press, 1990); Nantawan Haemindra, "The Problem of the Thai Muslims in the Four Southern Provinces of Thailand (Part One)," Journal of Southeast Asian Studies 7, no. 2 (1976): 202225.

35. Haemindra, "The Problem of the Thai Muslims in the Four Southern Provinces of Thailand (Part One)" (see note 34 above); Che Man, Muslim Separatism (see note 34 above); Raymond Scupin, "Muslim Accommodation in Thai Society," Journal of Islamic Studies 9, no. 2 (1998): 229258.

36. International Crisis Group, "Southern Thailand: Insurgency, not Jihad," Asia Report 98 (2005): 10; Chaiwat Satha Anand, Islam and Violence: A Case Study of Violent Events in the Four Southern Provinces, Thailand, 19761981 (Tampa: USF Monographs in Religion and Public Policy, University of South Florida, 1987).

37. Che Man, Muslim Separatism (see note 34 above); Moshe Yegar, Between Integration and Secession: The Muslim Communities of the Southern Philippines, Southern Thailand, and Western Burma/Myanmar (Oxford: Lexington Books, 2002).

38. Human Rights Watch, No One is Safe: Insurgent Attacks on Civilians in Thailand's Southern Border Provinces 19, no. 13 (2007): 8; Wattana Sugunnasil, "Islam, Radicalism, and Violence in Southern Thailand: Berjihad die Pattani and the 28 April 2004 Attacks," in Duncan McCargo, ed., Rethinking Thailand's Southern Violence (National University of Singapore Press, 2007), 112 136; International Crisis Group, "Southern Thailand: Insurgency, not Jihad" (see note 36 above).

39. Duncan McCargo, Tearing Apart the Land: Islam and Legitimacy in Southern Thailand (London/Ithaca: Cornell University Press, 2008); Horstmann, "Ethnohistorical Per spectives on Buddhist Muslim Relations and Coexistence in Southern Thailand" (see note 33 above). 
40. Imtiyaz Yusuf, "Faces of Islam in Southern Thailand," Working Paper 7, East West Center, 2007; Scupin, "Muslim Accommodation in Thai Society" (see note 35 above); Surin Pitsuwan, Islam and Malay Nationalism: A Case Study of the Malay Muslims of Southern Thailand (Bangkok: Thammasat University, 1985), 248249.

41. Alexander Horstmann, "The Inculturation of a Transnational Islamic Missionary Movement: Tablighi Jamaat al Dawa and Muslim Society in Southern Thailand," SOJOURN 22, no. 1 (2007): 107 130; McCargo, Tearing Apart the Land (see note 39 above).

42. Yusuf, "Faces of Islam in Southern Thailand" (see note 40 above); Horstmann, "Ethnohistorical Perspectives on Buddhist Muslim Relations and Coexistence in Southern Thailand" (see note 33 above); McCargo, Tearing Apart the Land (see note 39 above); Scupin, "Muslim Accommodation in Thai Society" (see note 35 above), 253.

43. Che Man, Muslim Separatism (see note 34 above); International Crisis Group, "Southern Thailand" (note 36 above); McCargo, Tearing Apart the Land (see note 39 above).

44. Walter Posch, "A Majority Ignored: The Arabs in Iraq," in Walter Posch, ed., Looking into Iraq, Chaillot Paper Nr. 79 (Paris: Institute for Security Studies, European Union, 2005), 25 44; Anthony H. Cordesman, Iraq's Evolving Insurgency and the Risk of Civil War (Washington, DC: Center for Strategic and International Studies, 2006), 193.

45. International Crisis Group, "The Next Iraqi War? Sectarianism and Civil Conflict," Middle East Report 52 (2006): 5; Guido Steinberg, Die Irakische Aufstandsbewegung. Akteure, Strategien und Strukturen (Berlin: Stiftung Wissenschaft und Politik, 2006); Ashraf al Khalidi and Victor Tanner, Sectarian Violence: Radical Groups Drive Internal Displace ment in Iraq (Washington, DC: Occasional Paper of the Brookings Institution University of Bern Project on Internal Displacement, 2006); Toby Dodge, "Order and Violence in Post Saddam Iraq," Adelphi Papers 45, no. 372 (2005): 9 23; Juan Cole, "The United States and Shi'ite Religious Factions in Post Ba'thist Iraq," Middle East Journal 57, no. 4 (2003): 543566

46. International Crisis Group, “Iraq's Muqtada al Sadr: Spoiler or Stabiliser?,” Middle East Report 55 (2006): 10, 18. 202.

47. Cordesman, Iraq's Evolving Insurgency and the Risk of Civil War (see note 44 above),

48. al Khalidi and Tanner, Sectarian Violence (see note 45 above), 12.

49. International Crisis Group, "The Next Iraqi War?" (see note 45 above), 8; Cole, "The United States and Shi'ite Religious Factions in Post Ba'thist Iraq" (see note 45 above).

50. Cole, "The United States and Shi'ite Religious Factions in Post Ba'thist Iraq" (see note 45 above); Babak Rahimi, Ayatollah Sistani and the Democratization of Post Ba'athist Iraq (Special Report) (Washington, DC: United Institute of Peace, 2007).

51. Cole, "The United States and Shi'ite Religious Factions in Post Ba'thist Iraq" (see note 45 above); Yitzhak Nakkash, Reaching for Power: The Shia in the Modern Arab World (Princeton, NJ: Princeton University Press, 2006); Ferhad Ibrahim, Konfessionalismus und Politik in der Arabischen Welt: Die Schiiten im Irak (Münster: LIT, 1997).

52. Cole, "The United States and Shi'ite Religious Factions in Post Ba'thist Iraq" (see note 45 above), 565 .

53. Rahimi, Ayatollah Sistani and the Democratization of Post Ba'athist Iraq (see note 50 above).

54. International Crisis Group, "Iraq's Shiites under Occupation," Middle East Briefing (September 2003); Cole, "The United States and Shi'ite Religious Factions in Post Ba'thist Iraq" (see note 45 above).

55. Maria Lorenza Palm Dalupan, "The Religious Sector Building Peace: Some Examples From the Philippines," in Gerrie ter Haar and James J. Busuttil, eds., Bridge or Barrier: Religion, Violence and Visions for Peace (Leiden/Boston: Brill, 2005), 233; Thomas M. McKenna, "Saints, Scholars and the Idealized Past in Philippine Muslim Separatism," The Pacific Review 15, no. 4 (2002): 539 553; Thayil Jacob Sony George, Revolt in Mindanao: The Rise of Islam in Philippine Politics (Kuala Lumpur: Oxford University Press, 1980).

56. McKenna, "Saints, Scholars and the Idealized Past in Philippine Muslim Separatism" (see note 55 above); Jan Stark, "Muslims in the Philippines," Journal of Muslim Minority Affairs 23, no. 1 (2003): 195 209; Yegar, Between Integration and Secession (see note 37 above), 277.

57. Cited after Thomas M. McKenna, Muslim Rulers and Rebels: Everyday Politics and Armed Separatism in the Southern Philippines (Berkeley: University of California Press, 1998), 208. 
58. Yegar, Between Integration and Secession (see note 37 above), 343.

59. McKenna, Muslim Rulers and Rebels (see note 57 above); Cesar Adib Majul, "The Moro Struggle in the Philippines," Third World Quarterly 10, no. 2 (1988): 897922.

60. Eric Gutierrez, "Religion and Politics in Muslim Mindanao," in Kristina Gaerlan and Mara Stankovitch, eds., Rebels, Warlords and Ulama: A Reader on Muslim Separatism and the War in Southern Philippines (Quezon City, Philippines: Institute for Popular Democracy, 2000), 146 161; McKenna, Muslim Rulers and Rebels (see note 57 above), 184; Che Man, Muslim Separatism (see note 34 above), 84.

61. McKenna, Muslim Rulers and Rebelss (see note 57 above), 232; Zachary Abuza, "The Moro Islamic Liberation Front at 20: State of the Revolution," Studies in Conflict and Terrorism 28 (2005): 453479.

62. George, Revolt in Mindanao: The Rise of Islam in Philippine Politics (see note 55 above); McKenna, Muslim Rulers and Rebels (see note 57 above).

63. Peter Kreuzer, Die Rebellion der Muslime im Süden der Philippinen (Frankfurt am Main: Hessische Stiftung Friedens und Konfliktforschung, Report 7/2003).

64. Majul, "The Moro Struggle in the Philippines" (see note 59 above); McKenna, Muslim Rulers and Rebels (see note 57 above); Kreuzer, Die Rebellion der Muslime im Süden der Philippinen (see note 63 above).

65. Cesar Adib Majul, The Contemporary Muslim Movement in the Philippines (Manila: Mizan Press, 1985); McKenna, Muslim Rulers and Rebels (see note 57 above); Palm Dalupan, "The Religious Sector Building Peace" (see note 55 above), 225274.

66. McKenna, Muslim Rulers and Rebels (see note 57 above); Kreuzer, Die Rebellion der Muslime im Süden der Philippinen (see note 63 above).

67. Appleby, The Ambivalence of the Sacred (see note 5 above); Mark Juergensmeyer, The New Cold War? Religious Nationalism Confronts the Secular State (Oxford: University of California Press, 1993); Niels Kastfelt, "Religion and African Civil Wars: Themes and Interpretations," in Niels Kastfelt, ed., Religion and African Civil Wars (London: Hurst, 2005), 12 15; Richard English, Terrorism: How to Respond (Oxford: Oxford University Press, 2009). 